Original

\title{
Preventive Effects of Powdered Broccoli Sprout on Azoxymethane-induced Rat Colonic Aberrant Crypt Foci
}

\author{
Rikako Suzuki ${ }^{1,2}$, Hiroyuki Kohno ${ }^{1}$, Shigeyuki Sugie ${ }^{1}$, \\ Tadashi Okada ${ }^{3}$, and Takuji Tanaka ${ }^{1}$ \\ ${ }^{1}$ The First Department of Pathology, Kanazawa Medical University, 1-1 Daigaku, Uchinada, Ishikawa 920-0293, Japan \\ ${ }_{2}^{2}$ Research Fellow of the Japan Society for the Promotion of Science, 6 Ichibancho, Chiyoda-ku, Tokyo 102-8471, Japan \\ ${ }^{3}$ Oryza Oil \& Fat Chemical Co. Ltd., 1 Numata, Kitagata-cho, Ichinomiya, Aichi 493-8001, Japan
}

\begin{abstract}
The modifying effects of dietary feeding of powdered broccoli sprout (PBS), which contained a high concentration of sulforaphane, on the development of azoxymethane (AOM)-induced colonic aberrant crypt foci (ACF) were investigated in male F344 rats. We also determined the influence of PBS on proliferating cell nuclear antigen (PCNA) index in "normal-appearing" crypts from rats treated with AOM and/or PBS, and activities of detoxifying enzymes of cytochrome P450 (CYP) and glutathione $S$-transferase (GST) in the liver. Rats were given two weekly subcutaneous injections of AOM $(20 \mathrm{mg} / \mathrm{kg}$ body wt $)$ to produce ACF. They also received experimental diets containing PBS at a dose of 20 or $100 \mathrm{ppm}$ for 4 weeks, starting 1 week before the first dose of AOM. AOM exposure induced a substantial number of ACF $(106 \pm 10)$ at the end of the study (week 4). Dietary administration of PBS caused significant reduction in the frequency of ACF: 20 ppm PBS, $56 \pm 11$ (47\% reduction, $\mathrm{P}<0.001)$ and $100 \mathrm{ppm}$ PBS, $64 \pm 23(40 \%$ reduction, $\mathrm{P}<0.001$ ). Immunohistochemically, PBS administration at both doses significantly lowered the PCNA index in "normal-appearing" crypts. In addition, feeding with PBS significantly reduced the activities of CYP 2B and CYP $3 \mathrm{~A}$, and slightly increased GST activity in the liver. These findings suggest a possible chemopreventive ability of PBS through alterations to the activities of cell proliferation in cryptal cells in the colon and activities of drug metabolizing enzymes in the liver. (J Toxicol Pathol 2004; 17: 119-126)
\end{abstract}

Key words: broccoli sprout, aberrant crypt foci, inhibition, rat colon

\section{Introduction}

Cancer death is an important public health concern around the world. Despite advances in early detection, and basic and clinical trials of promising new therapies, morbidity and mortality of cancer remain major factors in public health ${ }^{1}$. Among the cancers, colorectal cancer is a leading cause of cancer deaths in the United States and is increasing in $\mathrm{Asia}^{2,3}$. The dietary intake of agents preventing cancer or dietary recommendations is probably of great importance in cancer prevention ${ }^{4}$. A large number of epidemiologic and animal studies imply that consumption of higher levels of vegetables and fruits reduces the risks of several types of cancer, including colon cancer ${ }^{5-8}$. Many potentially anticarcinogenic agents are found in food sources $^{6}$, and particularly cruciferous vegetables are associated with a reduced incidence of cancer ${ }^{9-12}$.

\section{Received: 5 April 2004, Accepted: 21 May 2004}

Mailing address: Rikako Suzuki, The First Department of Pathology, Kanazawa Medical University, 1-1 Daigaku, Uchinada, Ishikawa 920-0293, Japan

TEL: 81-76-286-2211 FAX: 81-76-286-6926

E-mail: rikako@kanazawa-med.ac.jp
Broccoli is a cruciferous vegetable which contains some potentially anticarcinogenic phytochemicals such as carotenoids, phenols, indoles, and isothiocyanates. Sulforaphane is one of the isothiocyanates and is the main isothiocyanate found in broccoli sprout. There are several studies showing its chemopreventive potential for carcinogenesis in the prostate ${ }^{13}$, mammary $^{14}$, stomach $^{15}$, and colon ${ }^{16,17}$. Broccoli also has other active constituents, namely indole-3-carbinol, chlorogenic acid, protocatechuic acid, and $\beta$-carotene. Broccoli sprout is an especially good source of the chemoprotective, glucosinolate, which is a precursor to isothiocyanate ${ }^{18}$, and is found in quantities 20 50 times greater than in mature broccoli ${ }^{19}$. Although the exact role of each compound that contributes to the protective effect needs to be identified, it is of interest to investigate the beneficial effects of broccoli, especially these of broccoli sprout on carcinogenesis.

Cytochrome P450 (CYP) isoenzymes are one major kind of phase I enzymes and play an important role in the oxidation of chemical compounds, often resulting in the formation of highly reactive compounds that are ultimately carcinogens ${ }^{20}$. Phase II enzymes, including glutathione $S$ transferase (GST), are responsible for catalyzing the 
biotransformation of a variety of electrophiles, and have a central role in the detoxification of activated metabolites of procarcinogens produced by phase I reactions. Thus, phase II detoxifying enzyme inducers are considered to be promising chemopreventive agents against cancer ${ }^{21}$.

In the current study, we investigated the possible inhibitory action of powdered broccoli sprout (PBS), which contained a high concentration of sulforaphane, in azoxymethane (AOM)-induced rat colonic aberrant crypt foci (ACF), putative precursor lesions of colon adenocarcinoma $^{22}$. We also evaluated the proliferating cell nuclear antigen (PCNA) index to assess whether PBS modifies cell proliferation activity in the cryptal cells. In addition, we assayed the effect of PBS on CYP and GST activities in the liver.

\section{Materials and Methods}

\section{Animals, chemicals, and diets}

Male F344 rats (Charles River Japan, Inc., Tokyo, Japan) aged 5 weeks were used. The animals were maintained at Kanazawa Medical University Animal Facility according to the Institutional Animal Care Guidelines. They were housed in plastic cages (4 rats/cage) with free access to tap water and diet, under controlled conditions of humidity $(50 \pm 10 \%)$, lighting (12-h light/dark cycle), and temperature $\left(23 \pm 2{ }^{\circ} \mathrm{C}\right)$. They were quarantined for 7 days and randomized by body weight into experimental and control groups. AOM for ACF induction was purchased from Sigma Chemical Co. (St. Louis, MO, USA). Powdered MF diet (Oriental Yeast, Co., Ltd., Tokyo Japan) was used as basal diet throughout the study. Powdered broccoli sprout (Oryza Oil \& Fat Chemical Co., Ltd., Ichinomiya, Japan) is a powder in which sulforaphane is concentrated in high content by machining broccoli (Brassica oleracea var. botrytis) sprouts. The composition of PBS is listed in Table 1. The experimental diet was made by mixing PBS (20 or $100 \mathrm{ppm}$ ) with the powdered basal MF diet using a rocking mixer (RM-10-2, Aichi Electric Co., Ltd., Kasugai City, Japan).

\section{Experimental procedure for ACF assay}

A total of 32 male F344 rats were divided into four experimental groups and a control group (Fig. 1). Animals in groups 1 through 3 were initiated with AOM by two weekly subcutaneous injections ( $20 \mathrm{mg} / \mathrm{kg}$ body weight). Rats in groups 2 and 3 were fed diets containing 20 and 100 ppm PBS for 4 weeks, respectively, starting one week before the first dosing with AOM. Group 4 did not receive AOM and were given the diet containing $100 \mathrm{ppm}$ PBS. Group 5 served as an untreated control. Rats were sacrificed under ether anesthesia at week 4 to assess the occurrence of colonic ACF. They underwent careful necropsy, with emphasis on the colon, liver, kidney, lung, and heart. All grossly abnormal lesions in any tissue, and the organs such as the liver (caudate lobe), kidney, lung and heart were fixed in $10 \%$ buffered formalin.
Table 1. Composition of PBS (100 g)

\begin{tabular}{lc}
\hline Moisture & $2.2 \mathrm{~g}$ \\
Protein & $45.2 \mathrm{~g}$ \\
Fat & $12.5 \mathrm{~g}$ \\
Fiber & $21.2 \mathrm{~g}$ \\
Ash & $5.4 \mathrm{~g}$ \\
Sulforaphane & $1.2 \mathrm{~g}$ \\
Indole-3-carbinol & $0.08 \mathrm{~g}$ \\
Vitamin A & $0.0005 \mathrm{~g}$ \\
Others & $12.2 \mathrm{~g}$ \\
\hline
\end{tabular}

Others include sugar, minerals, and unknown compounds.

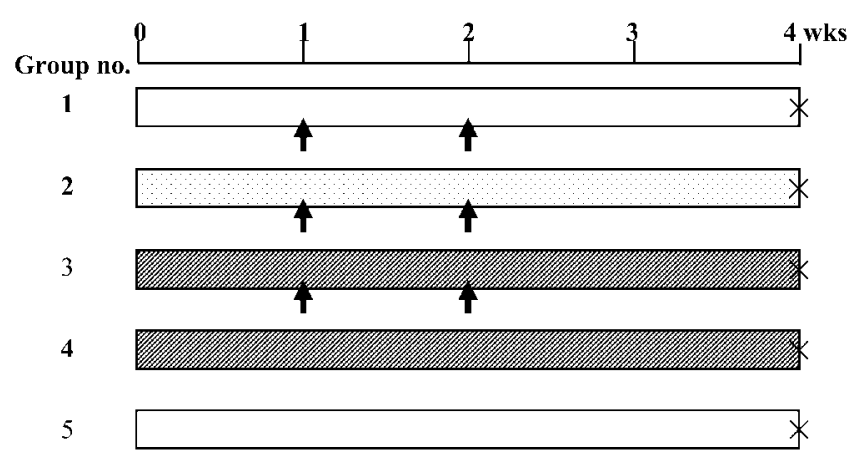

Fig. 1. Experimental protocol.
: Basal diet, 20 ppm PBS, 100 ppm PBS,
个: AOM, $20 \mathrm{mg} / \mathrm{kg}$ bw s.c., $\times$ : Sacrifice.

\section{Determination of $A C F$}

The frequency of ACF was determined according to the method described in our previous report ${ }^{23}$. At necropsy, the colons were flushed with saline, excised, cut open longitudinally along the main axis, and then washed with saline. They were cut and fixed in $10 \%$ buffered formalin for at least $24 \mathrm{~h}$. Fixed colons were dipped in a $0.5 \%$ solution of methylene blue in distilled water for $30 \mathrm{sec}$, briefly washed with the distilled water, and placed on a microscope slide for counting ACF.

\section{PCNA immunohistochemistry}

Immunohistochemical staining for PCNA was performed by the avidin-biotin complex method (Vecstain Elite ABC Kit, Vector, Burlingame, CA). Tissues were fixed in $10 \%$ buffered formalin for at least $24 \mathrm{~h}$, embedded in paraffin blocks, and $3 \mu \mathrm{m}$-thick paraffin-embedded sections were prepared. After that, they were deparaffinized with xylene, hydrated through a graded ethanol series, immersed in $0.3 \%$ hydrogen peroxide in absolute methanol for $30 \mathrm{~min}$ at room temperature to block endogenous peroxidase activity, and then washed in phosphate-buffered saline $(\mathrm{pH}$ 7.2). Following incubation with normal rabbit serum at room temperature for $10 \mathrm{~min}$ to block background staining, the sections were incubated with an anti-PCNA antibody (mouse monoclonal PC10, 1:100 dilution: Dako Co., Kyoto) for $12 \mathrm{~h}$ in a humidified chamber at room temperature. They 
Table 2. Body, Liver, and Relative Liver Weights and Food Consumption

\begin{tabular}{|c|c|c|c|c|c|}
\hline \multirow{2}{*}{ Group no. } & \multirow[b]{2}{*}{$\begin{array}{c}\text { Treatment } \\
\text { (no. of rats examined) }\end{array}$} & \multicolumn{3}{|c|}{ Terminal } & \multirow[b]{2}{*}{$\begin{array}{l}\text { Mean intake of } \\
\text { food/day/rat }(\mathrm{g})\end{array}$} \\
\hline & & $\begin{array}{l}\text { Body wt } \\
\text { (g) }\end{array}$ & $\begin{array}{l}\text { Liver wt } \\
\text { (g) }\end{array}$ & $\begin{array}{l}\text { Relative liver wt } \\
\text { (g/100 g body wt) }\end{array}$ & \\
\hline 1 & $\begin{array}{c}\text { AOM alone } \\
(8)\end{array}$ & $212 \pm 7^{a}$ & $10.7 \pm 1.0$ & $5.07 \pm 0.32$ & $12.0 \pm 1.2$ \\
\hline 2 & $\begin{array}{c}\mathrm{AOM}+20 \text { ppm PBS } \\
(8)\end{array}$ & $211 \pm 7$ & $10.7 \pm 1.2$ & $5.06 \pm 0.46$ & $12.3 \pm 1.9$ \\
\hline 3 & $\begin{array}{c}\mathrm{AOM}+100 \mathrm{ppm} \text { PBS } \\
(8)\end{array}$ & $218 \pm 6$ & $11.3 \pm 0.7$ & $5.21 \pm 0.26$ & $12.4 \pm 1.4$ \\
\hline 4 & $\begin{array}{c}100 \text { ppm PBS } \\
\text { (4) }\end{array}$ & $223 \pm 13$ & $10.5 \pm 0.6$ & $4.69 \pm 0.16$ & $14.5 \pm 3.4$ \\
\hline 5 & $\begin{array}{l}\text { No treatment } \\
\text { (4) }\end{array}$ & $214 \pm 7$ & $10.7 \pm 0.6$ & $4.97 \pm 0.20$ & $12.9 \pm 1.9$ \\
\hline
\end{tabular}

a: Mean \pm SD.

were then reacted with 3,3'-diaminobenzidine and lightly counterstained with Harris' hematoxylin. For determination of the PCNA-positive index, 10 full-length crypts of each colon were examined. The number and position of PCNA positively stained nuclei in each crypt column were recorded and expressed as the PCNA-positive index (number of positive stained nuclei $\times 100 /$ total number of nuclei counted). The observer was unaware of the group to which the specimens belonged.

Measurement of drug metabolizing enzymes in rat liver

The liver without caudate lobe was rinsed in cold $0.9 \%$ $\mathrm{NaCl}$, homogenized in ice-cold $50 \mathrm{mM}$ Tris buffer (pH 7.4) containing $0.15 \mathrm{M} \mathrm{KCl}$ to yield a $10 \%$ (wt/vol) homogenate, and then centrifuged at $10,000 \times \mathrm{g}$ for $60 \mathrm{~min}$ at $4{ }^{\circ} \mathrm{C}$. The supernatant (cytosol fraction), after discarding any floating lipid layer and appropriate dilution, was used for enzyme assays.

The concentration of total amount of CYP and cytochrome $b_{5}$ were quantified by the method of Omura and $\mathrm{Sato}^{24}$. NADPH-cytochrome P450 reductase activity was measured by the method of Phillips et al. ${ }^{25}$. For measurement of activities of CYP 1A1, CYP 1A2, and CYP $2 \mathrm{~B}$ levels using ethoxyresorufin $O$-deethylase, methoxyresorufin $O$-demethylase, and pentoxyresorufin $O$ depentylase as substrate, respectively ${ }^{26,27}$. P-Nitrophenol hydroxylase or testosterone $6 \beta$-transferase activities were used to determine CYP $2 \mathrm{E} 1^{28}$ or CYP $3 \mathrm{~A}^{29}$, respectively.

The cytosolic GST activity was determined spectrophotometrically at $340 \mathrm{~nm}$ with 1-chloro-2,4dinitrobenzene as a substrate according to the procedure of Habig et al. ${ }^{30}$

\section{Statistical evaluation}

Where applicable, data were analyzed using Student's $t$-test or Welch's $t$-test with $\mathrm{P}<0.05$ as the criterion for significance.

\section{Results}

\section{General observation}

Body, liver, relative liver weights (g/100 g body weight), and food consumption (g/day/rat) in all groups are shown in Table 2. All animals remained healthy throughout the experimental period. Food consumption (g/day/rat) did not differ significantly among the groups. At the end of the study, there were no significant differences in the mean weights of body and liver, and the relative liver weights among the groups.

\section{ACF Analysis}

Table 3 summarizes the data on colonic ACF formation (Fig. 2a). All rats belonging to groups 1 through 3, which were given AOM, developed ACF. The mean number of $\mathrm{ACF} /$ colon in group 1 (AOM alone) was $106 \pm 10$. The dietary administration of $20 \mathrm{ppm}$ (group 2) or $100 \mathrm{pm}$ (group 3) PBS significantly reduced the number of ACF compared to group 1: $56 \pm 11(47 \%$ reduction, $\mathrm{P}<0.001)$ in group 2 and $64 \pm 23(40 \%$ reduction, $\mathrm{P}<0.001)$ in group 3 . The percentages of ACF consisting of more than 4 crypts in group $2(2.2 \pm 1.4, \mathrm{P}<0.001)$ and group $3(2.2 \pm 1.8$, $\mathrm{P}<0.001)$ were significantly smaller than that of group $1(9.2$ \pm 1.3 ). In groups 4 and 5 , there was no microscopically observable change, including ACF, in colonic mucosa.

\section{PCNA-labeling index in "normal-appearing" and normal colonic crypts}

The PCNA-labeling indices in "normal-appearing" crypts from rats treated with AOM and /or PBS and normal colonic crypts from untreated rats are presented in Table 4 and Fig. 2 b-d. Dietary feeding with PBS significantly reduced the mean PCNA-labeling indices (\%): group 2, 18.8 $\pm 3.2, \mathrm{P}<0.01$; and group $3,14.4 \pm 4.8, \mathrm{P}<0.001$ in "normalappearing" crypts: vs. group $1,24.8 \pm 4$.6. Feeding with 100 ppm PBS alone (group 4) did not affect the PCNA-labeling index in normal crypts of rats, when compared with an untreated control group (group 5). 
Table 3. Effect of PBS on AOM-induced ACF Formation in Male F344 Rats

\begin{tabular}{ccccc}
\hline Group no. & $\begin{array}{c}\text { Treatment } \\
\text { (no. of rats examined) }\end{array}$ & $\begin{array}{c}\text { Incidence } \\
(\%)\end{array}$ & $\begin{array}{c}\text { Total no. of } \\
\text { ACF/colon }\end{array}$ & $\begin{array}{c}\text { \% of ACF containing } \\
4 \text { or more ACs }\end{array}$ \\
\hline 1 & AOM alone (8) & $8 / 8(100 \%)$ & $106 \pm 10^{\mathrm{a}}(100 \%)$ & $9.2 \pm 1.3(100 \%)$ \\
2 & AOM + 20 ppm PBS (8) & $8 / 8(100 \%)$ & $56 \pm 11^{\mathrm{b}}(53 \%)$ & $2.2 \pm 1.4^{\mathrm{b}}(24 \%)$ \\
3 & AOM + 100 ppm PBS (8) & $8 / 8(100 \%)$ & $64 \pm 23^{\mathrm{b}}(60 \%)$ & $2.2 \pm 1.8^{\mathrm{b}}(24 \%)$ \\
4 & 100 ppm PBS (4) & $0 / 4(0 \%)$ & 0 & 0 \\
5 & No treatment (4) & $0 / 4(0 \%)$ & 0 & 0 \\
\hline
\end{tabular}

ACF, aberrant crypt foci.

a: Mean \pm SD. b: Significantly different from group 1 by Welch's $t$-test or Student's $t$-test $(P<0.001)$.
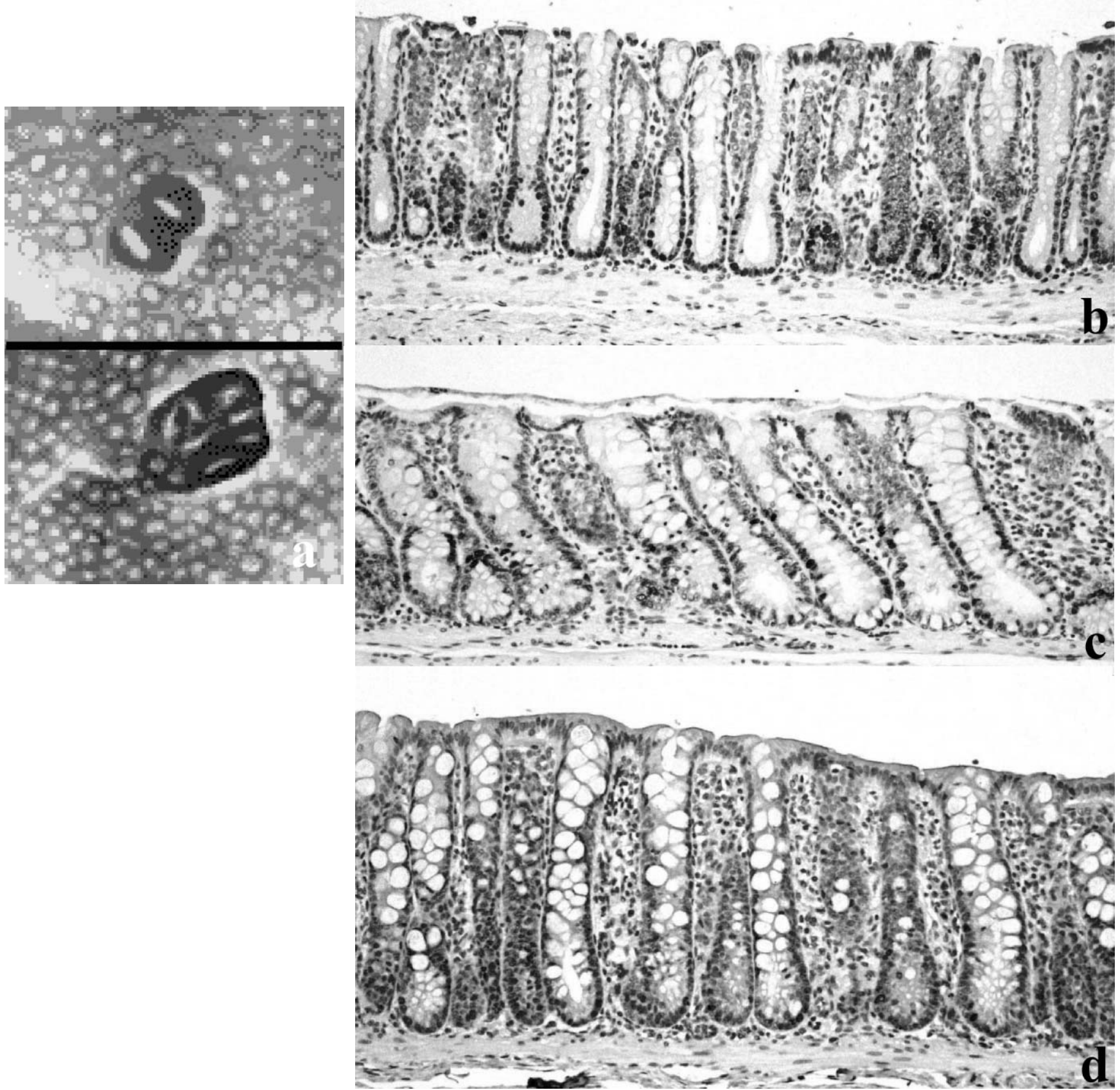

Fig. 2. Morphology of ACF and PCNA immunohistochemistry. a: ACF consisted of 2 and 9 aberrant crypts on methylene-blue-stained colonic mucosa of a rat in group 1; b: PCNA immunohistochemistry of "normal appearing" crypts of a rat from group 1; c: PCNA immunohistochemistry of "normal appearing" crypts of a rat from group 2; and d: PCNA immunohistochemistry of "normal appearing" crypts of a rat from group 3. Original magnifications, $a \times 4$; and $b-d \times 20$ 
Table 4. PCNA-labeling Index in Rectal Section of Colonic Mucosa

\begin{tabular}{clcc}
\hline Group no. & Treatment (no. of rats) & "Normal-appearing" crypts & Normal crypts \\
\hline 1 & AOM alone (8) & $24.8 \pm 4.6^{\mathrm{a}}$ & - \\
2 & AOM + 20 ppm PBS (8) & $18.8 \pm 3.2^{\mathrm{b}}$ & - \\
3 & AOM + 100 ppm PBS (8) & $14.4 \pm 4.8^{\mathrm{c}}$ & - \\
4 & 100 ppm PBS (4) & - & $11.5 \pm 2.4$ \\
5 & No treatment (4) & - & $11.5 \pm 1.3$ \\
\hline
\end{tabular}

a: Mean \pm SD.

b, c: Significantly different from group 1 by Welch's $t$-test (b: $P<0.01$, and c: $P<0.001$ ).

Table 5. Measurement of Drug Metabolizing Enzymes in Liver

\begin{tabular}{|c|c|c|c|c|c|}
\hline Group No. & $\begin{array}{c}1 \\
(\mathrm{AOM})\end{array}$ & $\begin{array}{l}2 \\
(\mathrm{AOM}+20 \mathrm{ppm} \mathrm{PBS})\end{array}$ & $\begin{array}{c}3 \\
(\mathrm{AOM}+100 \mathrm{ppm} \text { PBS })\end{array}$ & $\begin{array}{c}\quad 4 \\
(100 \mathrm{ppm} \text { PBS })\end{array}$ & $\begin{array}{c}5 \\
\text { (no treatment) }\end{array}$ \\
\hline Cytochrome P450 (nmol/mg) & $0.39 \pm 0.04^{\mathrm{a}}$ & $0.32 \pm 0.02^{\mathrm{b}}$ & $0.40 \pm 0.07$ & $0.49 \pm 0.04^{\mathrm{c}}$ & $0.35 \pm 0.08$ \\
\hline Cytochrome $b_{5}(\mathrm{nmol} / \mathrm{mg})$ & $0.33 \pm 0.03$ & $0.34 \pm 0.02$ & $0.35 \pm 0.03$ & $0.4 \pm 0.02$ & $0.35 \pm 0.04$ \\
\hline $\begin{array}{l}\text { NADPH- cytochrome } \mathrm{P} 450 \text { reductase } \\
(\mathrm{nmol} / \mathrm{min} / \mathrm{mg})\end{array}$ & $152 \pm 8$ & $143 \pm 22$ & $161 \pm 9$ & $170 \pm 13$ & $149 \pm 17$ \\
\hline EROD $(\mathrm{pmol} / \mathrm{min} / \mathrm{mg})$ & $90 \pm 15$ & $61 \pm 3^{\mathrm{b}}$ & $86 \pm 10$ & $70 \pm 12$ & $75 \pm 13$ \\
\hline MROD (pmol/min/mg) & $31.2 \pm 4.6$ & $22.7 \pm 8.5$ & $33.1 \pm 4.0$ & $24.4 \pm 4.8$ & $30.9 \pm 4.7$ \\
\hline PROD (pmol/min/mg) & $7.4 \pm 1.2^{\mathrm{d}}$ & $4.46 \pm 0.56^{\mathrm{e}}$ & $4.59 \pm 0.81^{\mathrm{f}}$ & $5.05 \pm 0.93$ & $3.71 \pm 0.95$ \\
\hline PNPH (nmol/min/mg) & $0.66 \pm 0.06$ & $0.77 \pm 0.16$ & $0.83 \pm 0.16$ & $0.92 \pm 0.20$ & $0.77 \pm 0.30$ \\
\hline $6 \beta-\mathrm{OH}(\mathrm{nmol} / \mathrm{min} / \mathrm{mg})$ & $1.58 \pm 0.10^{\mathrm{g}}$ & $0.63 \pm 0.09^{\mathrm{h}}$ & $0.59 \pm 0.03^{\mathrm{h}}$ & $0.58 \pm 0.08$ & $0.48 \pm 0.07$ \\
\hline
\end{tabular}

EROD, Ethoxyresorufin $O$-deethylase, CYP1A1; MROD, Methoxyresorufin $O$-demethylase, CYP1A2; PROD, Pentoxyresorufin O-depentylase, CYP2B; PNPH, $p$-Nitrophenol 2-hydroxylase, CYP2E1; $6 \beta$-OH, Testosterone $6 \beta$-hydroxylase, CYP3A.

a: Mean \pm SD.

$\mathrm{b}, \mathrm{e}, \mathrm{f}, \mathrm{h}$ : Significantly different from group 1 by Welch's $t$-test or Student's $t$-test (b: $P<0.05$, e: $P<0.005$, f: $P<0.01$, and h: $P<0.001$ ).

$\mathrm{c}, \mathrm{d}$, g: Significantly different from group 5 by Welch's $t$-test or Student's $t$-test (c: $P<0.05$, d: $P<0.005$, and g: $P<0.001$ ).

\section{Alterations of the CYP and GST in the liver}

Table 5 summarizes the content of CYP or cytochrome $b_{5}$ and the activity of NADPH-cytochrome $\mathrm{P} 450$ reductase in the liver. Dietary feeding with $20 \mathrm{ppm}$ PBS significantly reduced the content of CYP $(\mathrm{nmol} / \mathrm{mg})$ : group $2,0.32 \pm 0.02$ vs. group $1,0.39 \pm 0.04(\mathrm{P}<0.05)$. A significant increase of CYP was detected in group $4(0.49 \pm 0.04, \mathrm{P}<0.05)$ when compared to group $5(0.35 \pm 0.08)$. There were no significant differences among the groups for cytochrome $b_{5}$ and the activity of NADPH-cytochrome P450 reductase in the liver. Dietary feeding of PBS influenced the activities of CYP (Table 5). CYP 1A1 (pmol/min/mg) in group $2(61 \pm$ $3, \mathrm{P}<0.05)$ was significantly lower than that of group $1(90 \pm$ 15). The value of CYP 2B ( pmol $/ \mathrm{min} / \mathrm{mg})$ in group $1(7.4 \pm$ $1.2, \mathrm{P}<0.005)$ was significantly greater than that of group 5 (3.71 \pm 0.95$)$. The values in groups $2(4.46 \pm 0.56, \mathrm{P}<0.005)$ and $3(4.59 \pm 0.81, \mathrm{P}<0.01)$ were significantly smaller than that of group 1 . AOM exposure significantly elevated CYP $3 \mathrm{~A}$ activity $(1.58 \pm 0.10 \mathrm{nmol} / \mathrm{min} / \mathrm{mg}, \mathrm{P}<0.001)$ when compared to group $5(0.48 \pm 0.07)$. The treatment with PBS at both doses together with AOM significantly lowered this increase (group 2, $0.63 \pm 0.09, \mathrm{P}<0.001$; and group 3, $0.59 \pm$ $0.03, \mathrm{P}<0.001)$ when compared with group 1 . For activities of CYP $1 \mathrm{~A} 2$ and CYP 2E1, there were no significant differences among the groups.

For GST $(\mu \mathrm{mol} / \mathrm{min} / \mathrm{mg})$, the activity of group $1(0.90 \pm$ $0.11)$ was significantly greater than that of group $5(0.73 \pm$ $0.04)(\mathrm{P}<0.05$, Fig. 3$)$. Feeding with the diets containing PBS at both doses resulted in slight increases, when compared to the AOM alone group, and a significant difference was found between group $3(0.95 \pm 0.06)$ and group $5(\mathrm{P}<0.005)$.

\section{Discussion}

The results described here clearly indicate that dietary administration of PBS, which contains a high amount of sulforaphane, significantly reduced AOM-induced ACF formation in male rats. Also, rats fed the diets containing PBS showed no adverse effects on food consumption, growth rate, and no histological alterations in organs. These findings suggest that dietary PBS may suppress the early phase of chemically induced colon carcinogenesis.

Some explanations for the inhibitory effects of PBS on ACF-formation by AOM are considered. Cell proliferation has long been suspected to play a significant role in the 


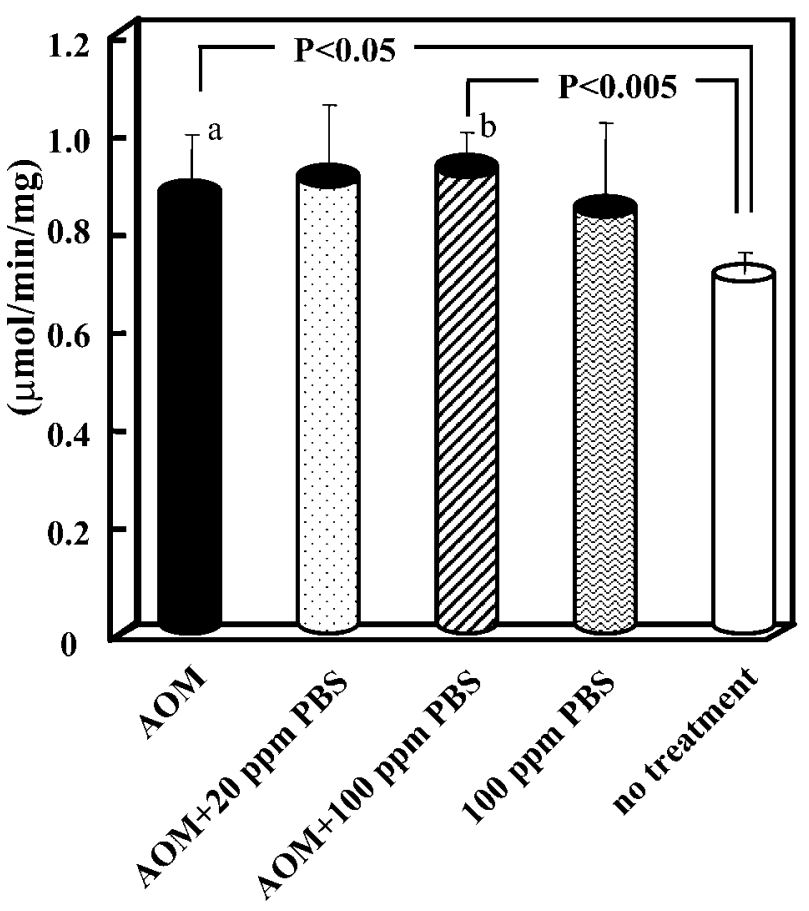

Fig. 3. Liver cytosolic GST activity.

initiation step as well as the promotion/progression of carcinogenesis $^{31,32}$. In the present study, the PCNA-labeling indices of "normal-appearing" crypts in the rectal section of colonic mucosa were significantly decreased by dietary administration of PBS. Thus, the inhibitory effect of PBS might be, in part, due to modification of cell proliferation activity in the cryptal cells. The apoptosis inducing effect of sulforaphane on HT-29 human colon cancer cell was recently reported ${ }^{17}$. This activity may also contribute to the inhibition of ACF formation, although we did not determine the apoptotic index in the colon.

CYP is known to play a prominent role in the modulation of xenobiotic metabolism including carcinogenic agent. CYP 2E1 is one of the important factors for converting AOM to methylazoxymethanol which can promote DNA adduct formation and follow the initiation event $^{33,34}$. Unexpectedly, feeding of PBS did not affect the activity of CYP 2E1 in the current study.

Dietary broccoli or isothiocyanate exposure modulates a variety of CYP activities in the liver, colon, and kidney of rats ${ }^{35,36}$. Maheo et al. ${ }^{37}$ reported that sulforaphane decreased the activities of CYP $1 \mathrm{~A} 1$ and $2 \mathrm{~B} 1 / 2$ in rat hepatocytes. In the current study, the enzyme activities of CYP $1 \mathrm{~A} 1,2 \mathrm{~B}$ and $3 \mathrm{~A}$ were decreased by feeding with PBS. Thus, alterations in CYP 1A1 and 2B activities might be caused by highly concentrated sulforaphane in PBS. There are few reports describing the association between these types of CYP and AOM-induced colon carcinogenesis, to our knowledge. However, we recently found that the reduction effect of extract of Ginkgo biloba leaves on the activity of liver CYP $3 \mathrm{~A}$ is related to its chemopreventive effect on AOM-induced rat colonic $\mathrm{ACF}^{38}$. Also, the amount of CYP $2 \mathrm{~B}$ in $\mathrm{FAO}$ cells (rat hepatocyte cell line) was decreased by treatment with dexamethasone ${ }^{39}$, which can inhibit the growth of colon carcinoma cell ${ }^{40}$. These findings suggest that downregulation of CYP $2 \mathrm{~B}$ and/or $3 \mathrm{~A}$ might cause the reduction of $\mathrm{AOM}$-induced $\mathrm{ACF}$ found in the current study.

There are some reports describing that dietary broccoli sprouts and their component glucosinolates and isothiocyanates induce phase II detoxication enzymes and this contributes to protection against chemical carcinogenesis in rodents ${ }^{41-43}$. Unfortunately, in the current study, a slight increase of GST activity was observed after PBS feeding. We suggest that the GST system was not involved in the inhibitory effect of PBS on ACF development in this study.

In the current study, we investigated the modifying effects of PBS on early stage rat colon carcinogenesis at two doses, and our results on the inhibitory potency of PBS in $\mathrm{ACF}$ formation were not dose-dependent. Also, the influence of PBS at two doses on CYPs and GST activities and PCNA-labeling measured in this study were comparable. These results may indicate that feeding PBS at a dose of $20 \mathrm{ppm}$ was enough to reduce colonic $\mathrm{ACF}$ development.

In conclusion, the findings described here demonstrate that dietary administration of PBS containing concentrated sulforaphane significantly inhibited the development of AOM-induced colonic ACF. Although the exact mechanisms by which PBS inhibits colonic ACF remain to be elucidated, it would be worthwhile to test the cancer chemoprevention ability of PBS in the colon with a longterm carcinogenesis model.

Acknowledgements: This research was supported in part by a Grant-in-Aid for the Second Term Comprehensive 10year Strategy for Cancer Control from the Ministry of Health, Labour and Welfare, Japan; by a Grant-in-Aid (no. 13671986) from the Ministry of Education, Culture, Sports, Science and Technology, Japan; and by a grant (H2002-6) for Project Research from High-Technology Center of Kanazawa Medical University. We thank Sotoe Yamamoto for her secretarial assistance and the staff of the Research Animal Facility of Kanazawa Medical University for taking good care of the animals.

\section{References}

1. Bailar JC3rd and Gornik HL. Cancer undefeated. N Engl J Med 1997; 336: 1569-1574.

2. Yamamoto S. Cancer Statistics Digest. All cancer mortality by prefectures in Japan. Jpn J Clin Oncol 2000; 30: 168.

3. Greenlee RT, Murray T, Bolden S, and Wingo PA. Cancer statistics, 2000. CA Cancer J Clin 2000; 50: 7-33.

4. Bruce A. Dietary recommendations in cancer prevention. Ann Clin Res 1987; 19: 313-320.

5. Hill MJ. Diet and cancer: a review of scientific evidence. Eur J Cancer Prev 1995; 4 (Suppl 2): 3-42.

6. Steinmetz KA and Potter JD. Vegetables, fruit, and cancer. 
II: mechanisms. Cancer Causes Control 1991; 2: 427-442.

7. Greenwald P, Clifford CK, and Milner JA. Diet and cancer prevention. Eur J Cancer 2001; 37: 948-965.

8. Tanaka T, Kohno H, and Mori H. Chemoprevention of Colon Carcinogenesis by Dietary Non-nutritive Compounds. Asian Pac J Cancer Prev 2001; 2: 165-177.

9. van Poppel G, Verhoeven DT, Verhagen H, and Goldbohm RA. Brassica vegetables and cancer prevention. Epidemiology and mechanisms. Adv Exp Med Biol 1999; 472: $159-168$.

10. Witte JS, Longnecker MP, Bird CL, Lee ER, Frankl HD, and Haile RW. Relation of vegetable, fruit, and grain consumption to colorectal adenomatous polyps. Am J Epidemiol 1996; 144: 1015-1025.

11. Park EJ and Pezzuto JM. Botanicals in cancer chemoprevention. Cancer Metastasis Rev 2002; 21: 231255.

12. Beecher CW. Cancer preventive properties of varieties of Brassica oleracea: a review. Am J Clin Nutr 1994; 59 (Suppl 5): 1166S-1170S.

13. Chiao JW, Chung FL, Kancherla R, Ahmed T, Mittelman A, and Conaway CC. Sulforaphane and its metabolite mediate growth arrest and apoptosis in human prostate cancer cells. Int J Oncol 2002; 20: 631-636.

14. Gerhauser C, You M, Liu J, Moriarty RM, Hawthorne M, Mehta RG, Moon RC, and Pezzuto JM. Cancer chemopreventive potential of sulforamate, a novel analogue of sulforaphane that induces phase 2 drug-metabolizing enzymes. Cancer Res 1997; 57: 272-278.

15. Fahey JW, Haristoy X, Dolan PM, Kensler TW, Scholtus I, Stephenson KK, Talalay P, and Lozniewski A. Sulforaphane inhibits extracellular, intracellular, and antibiotic-resistant strains of Helicobacter pylori and prevents benzo $[\alpha]$ pyreneinduced stomach tumors. Proc Natl Acad Sci USA 2002; 99: 7610-7615.

16. Chung FL, Conaway CC, Rao CV, and Reddy BS. Chemoprevention of colonic aberrant crypt foci in Fischer rats by sulforaphane and phenethyl isothiocyanate. Carcinogenesis 2000; 21: 2287-2291.

17. Gamet-Payrastre L, Li P, Lumeau S, Cassar G, Dupont MA, Chevolleau S, Gasc N, Tulliez J, and Terce F. Sulforaphane, a naturally occurring isothiocyanate, induces cell cycle arrest and apoptosis in HT29 human colon cancer cells. Cancer Res 2000; 60: 1426-1433.

18. Faulkner K, Mithen R, and Williamson G. Selective increase of the potential anticarcinogen 4-methylsulphinylbutyl glucosinolate in broccoli. Carcinogenesis 1998; 19: 605609.

19. Fahey JW, Zhang Y, and Talalay P. Broccoli sprouts: an exceptionally rich source of inducers of enzymes that protect against chemical carcinogens. Proc Natl Acad Sci USA 1997; 94: 10367-10372.

20. Guengerich FP. Roles of cytochrome P-450 enzymes in chemical carcinogenesis and cancer chemotherapy. Cancer Res 1988; 48: 2946-2954.

21. Wilkinson J 4th and Clapper ML. Detoxication enzymes and chemoprevention. Proc Soc Exp Biol Med 1997; 216: 192200.

22. Bird RP. Role of aberrant crypt foci in understanding the pathogenesis of colon cancer. Cancer Lett 1995; 93: 55-71.

23. Tanaka T, Kawabata K, Kakumoto M, Makita H, Hara A, Mori H, Satoh K, Hara A, Murakami A, Kuki W, Takahashi
Y, Yonei H, Koshimizu K, and Ohigashi H. Citrus auraptene inhibits chemically induced colonic aberrant crypt foci in male F344 rats. Carcinogenesis 1997; 18: 2155-2161.

24. Omura $\mathrm{T}$ and Sato R. The carbon monoxide-binding pigment of liver microsomes. I: evidence for its hemoprotein nature. J Biol Chem 1964; 239: 2370-2378.

25. Phillips $\mathrm{AH}$ and Langdon RG. Hepatic triphosphopyridine nucleotide-cytochrome c reductase: isolation, characterization, and kinetic studies. J Biol Chem 1962; 237: 2652-2660.

26. Pohl RJ and Fouts JR. A rapid method for assaying the metabolism of 7-ethoxyresorufin by microsomal subcellular fractions. Anal Biochem 1980; 107: 150-155.

27. Thapliyal R and Maru GB. Inhibition of cytochrome P450 isozymes by curcumins in vitro and in vivo. Food Chem Toxicol 2001; 39: 541-547.

28. Tassaneeyakul W, Veronese ME, Birkett DJ, and Miners JO. High-performance liquid chromatographic assay for 4nitrophenol hydroxylation, a putative cytochrome P-450 2E1 activity, in human liver microsomes. J Chromatogr 1993; 616: $73-78$.

29. Fukuda K, Ohta T, and Yamazoe Y. Grapefruit component interacting with rat and human P450 CYP3A: possible involvement of non-flavonoid components in drug interaction. Biol Pharm Bull 1997; 20: 560-564.

30. Habig WH, Pabst MJ, and Jakoby WB. Glutathione $S$ transferases: the first enzymatic step in mercapturic acid formation. J Biol Chem 1974; 249: 7130-7139.

31. Cohen SM and Ellwein LB. Cell proliferation in carcinogenesis. Science 1990; 249: 1007-1011.

32. Weisburger JH and Williams GM. Causes of cancer. In: Textbook of Clinical Oncology, GP Murphy, W Jr. Lawrence, and RE Jr. Lenhard (eds), Altanta, GA: American Cancer Society, 10-39, 1995.

33. Sohn OS, Ishizaki H, Yang CS, and Fiala ES. Metabolism of azoxymethane, methylazoxymethanol and $\mathrm{N}$ nitrosodimethylamine by cytochrome P450 IIE1. Carcinogenesis 1991; 12: 127-131.

34. Sohn OS, Fiala ES, Requeijo SP, Weisburger JH, and Gonzalez FJ. Differential effects of CYP2E1 status on the metabolic activation of the colon carcinogens azoxymethane and methylazoxymethanol. Cancer Res 2001 ; 61: 84358440.

35. Vang O, Frandsen H, Hansen KT, Sorensen JN, Sorensen H, and Andersen O. Biochemical effects of dietary intakes of different broccoli samples. I: differential modulation of cytochrome P-450 activities in rat liver, kidney, and colon. Metabolism 2001; 50: 1123-1129.

36. Vang O, Mortensen J, and Andersen O. Biochemical effects of dietary intake of different broccoli samples. II: multivariate analysis of contributions of specific glucosinolates in modulating cytochrome P-450 and antioxidant defense enzyme activities. Metabolism 2001; 50: 1130-1135.

37. Maheo K, Morel F, Langouet S, Kramer H, Le Ferrec E, Ketterer B, and Guillouzo A. Inhibition of cytochromes P450 and induction of glutathione $S$-transferases by sulforaphane in primary human and rat hepatocytes. Cancer Res 1997; 57: 3649-3652.

38. Suzuki R, Kohno H, Sugie S, Sasaki K, Yoshimura T, Wada $\mathrm{K}$, and Tanaka T. Preventive effects of extract of leaves of ginkgo (Ginkgo biloba) and its component bilobalide on 
azoxymethane-induced colonic aberrant crypt foci in rats. Cancer Lett 2004; in press.

39. de Waziers I, Bouguet J, Beaune PH, Gonzalez FJ, Ketterer $\mathrm{B}$, and Barouki R. Effects of ethanol, dexamethasone and RU 486 on expression of cytochromes P450 2B, 2E, 3A and glutathione transferase $\pi$ in a rat hepatoma cell line (Fao). Pharmacogenetics 1992; 2: 12-18.

40. Denis MG, Chadeneau C, Blanchardie P, and Lustenberger P. Biological effects of glucocorticoid hormones on two rat colon adenocarcinoma cell lines. J Steroid Biochem Mol Biol 1992; 41: 739-745.
41. Fahey JW and Talalay P. Antioxidant functions of sulforaphane: a potent inducer of Phase II detoxication enzymes. Food Chem Toxicol 1999; 37: 973-979.

42. Munday R and Munday CM. Selective induction of phase II enzymes in the urinary bladder of rats by allyl isothiocyanate, a compound derived from Brassica vegetables. Nutr Cancer 2002; 44: 52-59.

43. Zhang Y, Kensler TW, Cho CG, Posner GH, and Talalay P. Anticarcinogenic activities of sulforaphane and structurally related synthetic norbornyl isothiocyanates. Proc Natl Acad Sci USA 1994; 91: 3147-3150. 